\title{
Financial Inclusion through Digital Financial Services (DFS): A Study in Uganda
}

\author{
Jimmy Ebong ${ }^{1}$ and Babu George ${ }^{2, *(\mathbb{D}}$ \\ 1 Financial Sector Deepening Uganda, Kampala P.O. Box 608, Uganda; ebongjimmie@yahoo.co.uk \\ 2 School of Business, Christian Brothers University, 650 East Parkway South, Memphis, TN 38104, USA \\ * Correspondence: bgeorge@cbu.edu
}

Citation: Ebong, Jimmy, and Babu George. 2021. Financial Inclusion through Digital Financial Services (DFS): A Study in Uganda. Journal of Risk and Financial Management 14: 393. https://doi.org/10.3390/jrfm14090393

Academic Editor: Robert Hudson

Received: 23 July 2021

Accepted: 19 August 2021

Published: 24 August 2021

Publisher's Note: MDPI stays neutral with regard to jurisdictional claims in published maps and institutional affiliations.

Copyright: (c) 2021 by the authors. Licensee MDPI, Basel, Switzerland. This article is an open access article distributed under the terms and conditions of the Creative Commons Attribution (CC BY) license (https:// creativecommons.org/licenses/by/ $4.0 /)$

\begin{abstract}
This study unravels trends and momentum in banking and mobile money channels and uptake of select services and thereafter draws implications for enhancing financial inclusion through Digital Financial Services (DFS). The Rate of Change (ROC) approach was applied to analyze the growth momentum in banking and mobile money channels in Uganda. Implications for growth momentum in banking and mobile money channels for DFS and financial inclusion was drawn from observing and making informed interpretation of such observed trends and momentum. The findings of this study imply that banks must innovate to increase their contribution towards enhancing financial inclusion. Additional channel innovations, which may infuse banking and mobile money channels, are needed for banking to leverage on growth of mobile money and regain its role in enhancing financial inclusion. Leveraging the application of digital innovations in services such as payments and digitizing alternative channels such as agent banking are likely to increase efficiencies in physical channels and the provision of banking services and thereby increase overall reach and penetration of banking. The fast pace of mobile money penetration is good for speeding up financial inclusion. However, this calls for better regulatory approaches for DFS risk reduction, consumer protection, and protecting mobile money against integrity and financial crimes.
\end{abstract}

Keywords: financial services; inclusion; innovation; digital assets; Africa; Uganda

\section{Introduction}

Innovations in banking (Nkuna et al. 2018) and the proliferation of mobile money (GSMA 2016) have given rise to opportunities for growing Digital Financial Services (DFSs) and financial inclusion through alternative channels. Commercial banks represent the trusted, traditional avenue of integrating the unbanked into the formal financial system in most emerging economies. However, banking is changing, driven by changing consumer preferences and technology. Banks are adopting technology and innovation to deliver modern banking services efficiently through innovative models and alternative channels. Mobile money has become an efficient and convenient way of conducting various forms of financial transactions including transfers of funds, payments for services, access to microcredit (IMF 2019b) and, micro insurance. A convergence in mobile money and banking (IMF 2019b) is changing the outlook and terrain of payments.

DFSs are broadly defined to include a range of financial services which are accessed and delivered through digital channels. Such financial services include payments, credit, savings, remittances, and insurance. Financial inclusion encompasses various dimensions, including access to and usage of financial services, affordability (Iqbal and Sami 2017), quality of financial services and products, and capabilities of using such services to lead to the desired transformation in the situation of the user. IMF (2021) developed an integrated index of financial inclusion which includes access and usage of DFSs and traditional measures of financial inclusion. Financial services channels such as bank branches, ATMs, bank agent outlets, mobile money agent outlets motivate adoption and usage of financial services and consequently enhancing financial inclusion. 
In Eastern Africa, West Africa and South Asia (IMF 2019b) mobile money is the main driver of access and usage of financial services and financial inclusion. Demand-side surveys such as FinScope (FSDU 2018) show that mobile money has been the main driver of financial inclusion in emerging Uganda. Mobile money is becoming the channel for leveraging other financial services such as credit and insurance (IMF 2019b). Also, banks in many low- and middle-income countries are expanding financial access through agent outlets and bank agents. They do this by adopting technology innovations based on connectivity often provided by Mobile Network Operators (MNOs). Due to the changing landscape of financial services (GPFI 2016), partly driven by digitization, the need to raise awareness of the changing landscape and to promote the integration of financial inclusion objectives into guiding the formation of standards is brought to the limelight.

\section{Background}

Ouma et al. (2017) and Kar et al. (2011) document the theoretical link between economic growth and financial development. Their studies build on earlier studies (Hermes 1994; Levine 1997; Khan and Senhadji 2003; Trew 2006). According to Kar et al. (2011), views on relationships between economic growth and financial development fall into two categories. The first view can be traced to the work of Schumpeter (1911), which stresses the relevance of financial services in enhancing economic growth. According to Schumpeter (1911), financial institutions can proactively inspire invention and stimulate potential progress by identifying and allocating resources to finance investments that are productive. The role of financial institutions is in funding increases in aggregate production and GDP.

The second view expresses a reverse relationship between financial services and economic growth. This view is traceable to the work of Robinson (1952) who viewed access to finance as a somewhat insignificant element in the process of growth. Robinson (1952) contended that the demand for financial services will increase as output increases. In this case output growth influences financial development and uptake of financial services. This view that financial growth follows growth in output is echoed in part in a recent study conducted in India (Kumar 2013), on financial inclusion and its determinants. Kumar (2013) found that socio-economic setup and changes in such setups shape banking habits and the uptake of financial services. The theoretical perspectives reviewed above, provide ample evidence to support the argument that the relationship between economic growth and access and usage of financial services is bidirectional.

Iqbal and Sami (2017), El-Zoghbi (2019), Ogden (2019) postulate relationships between financial inclusion, economic growth, poverty reduction, and welfare improvement. According to Iqbal and Sami (2017), financial inclusion is instrumental to reduce poverty by enhancing societal economic progress. According to Nkuna et al. (2018), financial inclusion also enables reduction in income inequality and narrows the gap between the rich and poor. Evidence from theory consistently demonstrates that financial systems and services are important to households and that they drive economic growth and empirical studies based on micro and macro-economic data show that economic growth follows financial systems development (El-Zoghbi 2019).

Although many studies link financial inclusion to welfare improvement, householdlevel evidence linking financial inclusion to welfare improvement is scanty (El-Zoghbi 2019; Ogden 2019). This is because many studies do not get to the levels of nuances regarding relationships between financial inclusion, economic growth, and poverty reduction. As a result, there is no clear, compelling, and consistent evidence that links increasing financial inclusion to poverty reduction especially at the household level (Ogden 2019). According to El-Zoghbi (2019), there is no coherent, nuanced, and broader inclusive growth and finance story. In the absence of evidence linking financial inclusion to poverty, there have been questions concerning whether, where, and why financial inclusion matters.

Financial institutions facilitate the link between the use of financial services and any benefits related to economic growth and welfare improvement that arise from inclusion. 
According to Banto and Monsia (2021), the performance of banks improves GDP per capita through enhancing investment, consumption, and the development of human capital. Iqbal and Sami (2017) investigated how financial inclusion impacted growth in GDP of India over a period of seven years and found that increase in bank branches leads to an increase in credit deposit ratio and consequently an increase in GDP of a country. On the other hand, Iqbal, and Iqbal and Sami (2017) postulated that growth in ATMs increases convenience in the usage of deposit and withdrawal services but does not have a significant impact on GDP. Mobile money plays a significant role in leading to economic development (Ahmad et al. 2020). Uptake and usage of mobile money enable mobile money users to access social and economic services, consequently leading to economic empowerment and eventually the general wellbeing of service users (Amoah et al. 2020).

\section{Banking, Mobile Money, and Implications for Financial Inclusion}

Formal financial institutions may use technology-based solutions to provide several financial services to the poor and eventually lead to financial inclusion. The application of technology helps financial institutions to deliver uniform processes in banking as well as reduce costs of operation. According to Xv and Meng (2015), internet-based mobile finance developed by commercial banks constitutes innovations in the delivery of financial services and, as a result, can sharpen the competitive edge of the banks by lowering operational costs. According to Xv and Meng (2015), supportive national policies are crucial to enhance the development of digital financial services. Commercial banks may face operational challenges imposed by imperfect laws and regulations, competition, and shortage of talent and therefore supportive policies may help financial institutions to overcome such hurdles.

Ayyagari and Parahoo (2018) postulated that competition has forced banks to innovate and provide services through multiple channels, to meet different preferences of customers. Banks are leveraging physical and digital channels on the strengths of personal touch and the convenience of technology. Bank channels include branch services, online, smartphones, and ATMs. Each channel makes a different contribution towards enhancing the satisfaction of customers and fostering the continuity of banks' relationships with their customers. Human interaction, especially with customer service representatives (CSRs) determines the extent of customer satisfaction and continuous usage of services. To this effect, human interaction is still important and relevant to enable banks to satisfy and retain customers.

Technological innovation in banking is continuous and never-ending. Speed, accuracy, and efficiency have become pertinent in business (Vidyashree and Rathod 2018). IT-enabled banking services are being preferred as electronic channels enhance bank competitiveness. In rendering the advanced IT-enabled banking services, not only the banks might face some challenges in implementation but also customers may face challenges in the usage of IT-enabled services. From this perspective, overcoming challenges that customers face and handling customer complaints have implications for increasing uptake of IT-related and digital services through digital literacy and adequate protection of consumers who may not be digitally savvy.

Globally, banks are adopting multiple channel strategies (Agarwal and Mehrotra 2017). The right combination of banking channels can be arrived at only with a proper understanding of the preferences and perceptions of the consumers regarding the various channels. Agarwal and Mehrotra (2017) posit an increasing trend in the usage of mobile banking. Accessibility of the accounts is found to be the most important factor, whereas security is observed to be the least important factor in affecting customer's choice of a banking channel. A study by Mishra and Singh (2015) found that the ATM was the most preferred Electronic Banking Channel (EBC) alternative. This is followed by internet banking (IB) and mobile banking.

Mobile money contributes to financial inclusion (Ahmad et al. 2020), mainly by facilitating payments and remittances, but also by collecting user data that can be used to create a credit history to facilitate lending. This is especially key because financial inclusion should go beyond payments and remittances to include savings and credit. 
Further, consistent use of mobile money to access social and economic services promotes financial inclusion (Amoah et al. 2020). According to AFI (2014), mobile financial services (MFS) are driving financial inclusion. Mobile money conduit is synonymous with and is almost becoming the new system for electronic payments (Merritt 2011). Money transfer and remittance services around the world are shifting from traditional providers to wireless carriers who are efficient and affordable and can compete for a sizeable consumer market share based on deploying technologies and lowering their costs.

Mobile money adoption rates differ significantly across countries, and the success of mobile money innovations is also radically different within countries (Lashitew et al. 2019). Factors that drive financial inclusion arising from the adoption and usage of mobile money include age, digital literacy and availability of associated services such as phone credit recharge, education, and income (Amoah et al. 2020). Further, entrepreneurship, gender, living in urban or rural areas all positively influence the probability to adopt and use mobile money (Myeni et al. 2020). Also, the density of registered mobile money agents per 100,000 adults led to an increase in the total number of people using the financial services per 100,000 adults in Sub-Sahara Africa and the relationship between the registered mobile money agents per 100,000 adults and the total number of people using financial services was proven to be significant (Nyimbiri 2021).

According to Nkuna et al. (2018), alternative channels, particularly agent banking, have played a great role in expanding financial inclusion and taking services of commercial banks to rural areas. Roles that banks have played in reaching the underserved population include providing financial literacy to their customer segments, setting lower requirements for accounts hence making services affordable and putting them in place as well as observing consumer protection requirements. Findings of Nkuna et al. (2018) state that most banks still perceive fees and charges, distance to bank outlets, Know Your Customer (KYC) requirements, and low literacy levels as being major barriers to uptake and usage of banking services and consequently enhancing financial inclusion through banks. Fees and charges, as well as Know Your Customer (KYC) are regulatory requirements with which banks must comply. According to Xv and Meng (2015), banks can work around regulatory hurdles and build a suitable mobile finance ecosphere. Xv and Meng (2015), also emphasize the role of banks in enhancing financial innovations. Banks may innovate through talent management, analyzing markets and identifying opportunities, as well as collaborating with other organizations. Such collaborations may be extended to include collaborations with MNOs.

According to Kaur et al. (2021), in-branch efforts play significant roles in enhancing the adoption of digital banking. In-branch efforts include communication with customers, digital transformation of the branch, deliberate customer-centric initiatives, and redefined role of branch staff. Such efforts potentially influence, as well as facilitate customers' shift to digital banking. According to Kaur et al. (2021) gaining customers' confidence and trust in digital banking is relevant to enhance acceptance of digital banking. Also, the study suggests that human factors such as cultural and organizational changes at the bank's level are necessary to enable banks to gain digital banking acceptance.

According to Vidyashree and Rathod (2018), customer awareness influences the adoption of IT-enabled banking services applied in electronic banking channels. Creating customer awareness in how to use the services is likely to increase adoption. According to Agarwal and Mehrotra (2017), accessibility is found to be the most important factor, whereas security is observed to be the least important factor that affects customer's choice of a banking channel. Also, Mishra and Singh (2015) posit that awareness, self-efficacy, ease of use, usefulness of the service, and security during depositing or withdrawing are responsible for making ATMs the most preferred channel.

According to Aron (2018) mobile money, a contemporary innovation through which financial services are provided via mobile phones, has spread rapidly in the developing world, overtaking banking. This is because mobile money solves the problem of weak institutional infrastructure that made the cost of conventional banking high. According to 
Aron (2018), mobile money fosters risk-sharing, but direct evidence of the promotion of welfare and saving is still mostly rather less robust.

IMF (2019b) reports a convergence in mobile money and banking. Banks in many low- and middle-income countries are expanding financial access through agent outlets and bank agents, leveraging internet connectivity provided by MNOs. In the case of mobile banking, banking services are used in combination with mobile money, and this effectively increases the uptake of both mobile money and banking services. Individuals who use mobile money are $19 \%$ more likely to own a bank account at a formal financial institution with a higher probability estimate observed amongst rural residents (Myeni et al. 2020). The pace of increase in adoption of mobile money (Aron 2018), the high rate of adoption of mobile money in payments and remittances (Ahmad et al. 2020), the requirement for digital literacy in the usage of digital services (Amoah et al. 2020), and the standardization of IT-enabled services (Vidyashree and Rathod 2018) pose an implication for the consideration of consumer protection. According to Noronha and Kumar (2019), the application of technology helps financial institutions to standardize products and services. Yet standardization may violate the fair treatment and discrimination rules of consumer protection. According to AFI (2014), having an effective consumer protection guideline in place can help to build consumer trust and confidence, which in turn can improve uptake and usage.

The importance of a supportive regulatory environment (Lashitew et al. 2019) in enhancing financial inclusion cannot be downplayed. The requirement for a favorable regulatory environment poses implications for how best to regulate. Regulation must balance between mitigating the risk to users, which arises from the uptake of financial services and innovation. Merritt (2011) posits the risks from payment systems cutting across geographic borders embodying different legal and regulatory jurisdictions, as well as the emergence of mobile airtime as an alternative form of currency. Also, cross-border remittances are likely to pose a systemic risk (Merritt 2011) from the context of both developed and emerging countries and more so considering the participation of banks and non-bank telecom firms in how mobile money operates. In the case of Safaricom's M-Pesa in Kenya, mobile money poses regulatory challenges arising from the market structure and competition mechanisms and pricing of services (Ahmad et al. 2020). The power and interest dynamics of key actors in the innovation system can shape or distort inclusiveness in innovations that aim to address social issues (Lashitew et al. 2019).

Mobile money is presented as a way of reducing non-transparent cash movements and transfers in many developing countries and hence a way to combat money laundering and financing terrorism (de Koker 2013). On the other hand, Chatain et al. (2013) and de Koker (2013) posit that mobile money also faces integrity challenges and other challenges associated with financial crimes such as money laundering and financing terrorism. Crafting regulations that promulgate the role of mobile money in enhancing financial inclusion that are also compliant with anti-money laundering (AML) and combating the financing of Terrorism (CFT) is a challenge. Further, there is a misalignment of CFT and AML regulations with the business models of mobile money. Consequently, AML and CFT regulations are prohibitive to the growth of mobile money. The standard setting is playing a role in enhancing financial inclusion by way of helping to navigate the challenges of mobile money. According to Harris et al. (2013), the adoption of mobile money comes with concerns over privacy and users' security as well as transparency. These concerns are valid, particularly in the case of developing countries where the rule of law is weak. Weak governance leaves service users vulnerable. These matters of privacy, security and transparency call for strengthening policies especially toward enhancing consumer privacy and cybersecurity and corporate conducts of the MNOs.

Regarding privacy risks, UCC (2021) reports a global increase in online privacy vulnerabilities and hacking, which poses new global regulatory challenges. Hacking and associated vulnerabilities also apply to mobile money accounts in Uganda. With regard to data laws, consent, and third-party data sharing, CFI (2021) reports that users are often 
highly willing to exchange their personal data for financial services. Further, the risks of DFS extend beyond integrity, financial crimes, and privacy and data laws to include the indebtedness of users. The indebtedness of users has been documented in credit markets across Eastern Africa (Ebong and George 2020).

\section{Scope of the Study}

Trust is related to the adoption and usage of DFS (AFI 2014). Globally, about a third $(30 \%)$ of registered mobile money accounts are active (GSMA 2016). The global picture of low usage of accounts is also replicated at the national level. The global and national scenario of low adoption and usage of mobile money accounts is an indication of the low levels of trust that users have regarding mobile money services. Account dormancy raises both criminal and integrity concerns (de koker 2018) associated with mobile money. Further, the growth of DFS poses a risk associated with the exposure of customer funds, solvency, liquidity, settlement, and protection of consumers' funds (GSMA 2016). These risks have given rise to a need for regulations to monitor the exposure of customers but also regulation to boost customers' trust in mobile money and DFS and increase account usage.

Comprehension of trends and growth in banking and mobile money channels is relevant to enhance innovations in DFS and enhancing financial inclusion. In addition, insight regarding growth in banking and mobile money channel is also relevant in identifying opportunities for reducing DFS risks and responsibly deepening penetration as well as uptake of Digital Financial Services (DFS) and boosting financial inclusion. Therefore, the purpose of this study is to analyze Financial Access Survey (FAS) supply-side data and unravel nuances in trends and growth momentum in banking and mobile money channels and uptake of services and draw implications for advancing financial inclusion through innovations in DFS.

The main objective of this study is to assess, analyze and examine trends and growth momentum in banking and mobile money penetration and uptake of services in Uganda. Specific objectives include the following.

(a) Assess trends and momentum in penetration of banking channels and the uptake of deposits and borrowings through banks.

(b) Analyze trends and momentum in the penetration of mobile money and the access and usage of mobile money services.

(c) Draw implications of trends and momentum in penetration and uptake of banking and mobile money channels and uptake of services for financial inclusion through innovations in DFS.

Consistent with its purpose and objectives, this study endeavored to answer three key research questions, which are presented as follows.

(a) What is the trend and momentum in the penetration of banking channels and the uptake of deposits and borrowings?

(b) What is the trend and momentum in the penetration of mobile money and the uptake of mobile money services?

(c) What is the implication of trends and momentum in penetration and uptake of banking and mobile money channels and services in (a) and (b) for enhancing financial inclusion through Digital Financial Services (DFS)?

The scope of the study covers trends and growth momentum in banking and mobile money channels and uptake of financial services. For banking, the analysis included penetration of physical channels such as bank branches and ATMs and uptake of borrowing and deposits. For mobile money, the analysis included trends in registered mobile money agent outlets and adoption of mobile money or penetration of mobile money transactions.

This study is significant for innovators working with Fintech companies. The study provides insights that enhance their understanding and appreciation of trends and growth momentum in both banking and mobile money channels and uptake of services. Innova- 
tors need such insights, especially to inform their strategic posture and how they should approach the development of financial products and services that are accessed using mobile money channels. Such insights also inform how innovators must approach strategic partnerships. Further, mainly short notes from IMF FAS surveys concurrently report trends in mobile money and banking, albeit at an aggregated global level. This study systematically combines and investigates mobile money and banking channels and uptake of services for the case of Uganda, thus contributing to knowledge that informs interventions and innovations for enhancing financial inclusion through DFS in Uganda.

\section{Methodology}

The data for this study were obtained from the Financial Access Survey (FAS) website (data.imf.org). The researcher downloaded the dataset in an Excel spreadsheet and reviewed it for consistency, preparing it for analysis. Data were then analyzed to derive trends and growth momentum in banking and mobile money channels. The Financial Access Survey (FAS) is a supply-side dataset on access to and use of banking and mobile money services. The FAS started collecting data on mobile money in 2014. Data for banking were available from 2005 to 2019. IMF defines adults to be individuals of 15 years of age and older as per the FAS guideline and manual (IMF 2019a, p. 6).

The source of the mobile money data of FAS is administrative, obtained from regulators of mobile money and banking service providers in respective economies from which data is collected. Currently, there are close to 90 economies in which mobile money services are available (GSMA 2017), out of which 66 report data to the FAS. Mobile money data for the period of analysis are available with the Uganda Communications Commission (UCC) and Bank of Uganda (BOU). The National Payment Systems (NPS) Act, 2020, and the NPS Implementing Regulations, 2021 has recently mandated BOU to regulate mobile money. Consequently, BOU issued licenses to Airtel Mobile Commerce Uganda Limited and MTN Mobile Money Uganda Limited to become Payment Systems Operators (PSPs). Airtel Mobile Commerce Uganda Limited and MTN Mobile Money Uganda Limited previously operated Airtel and MTN mobile money services, respectively. This development shifted data responsibility to BOU.

According to Angela (2016), the main advantage of using secondary data is that it saves costs. The main disadvantage arises out of consideration for validity. Validity in research is concerned with whether the measures that the previous researcher who collected the data used for data collection are appropriate. The researcher overcame the problem of validity by comparing the IMF data set with existing data sets from, UCC and that from BOU and reviewing the literature on mobile money and banking in Uganda and similarly from GSMA.

Mobile money data from IMF, UCC, and BOU are aligned in the sense that they all show growth in mobile money services. However, absolute numbers and estimates of various mobile money indicators from these institutions vary. According to UCC (UCC 2020), in the third quarter of 2020, there were 1.8 million new subscribers. According to BOU, registered customers grew from 27 million in 2019 to 30 million in 2020, indicating a $12 \%$ growth. IMF data are consistent with those of BOU but seem lower than the estimates by UCC. According to UCC's Market Performance Report (UCC 2021), active mobile money accounts are estimated at 20.3 million at the end of March 2021. According to IMF and $\mathrm{BOU}$, registered customers had reached 30 million in 2020. Considering that only about $30 \%$ of registered accounts are active (GSMA 2016), it can be concluded that UCC estimates of active mobile money accounts are higher than the estimates by IMF and BOU.

The rate of change (ROC) was applied to obtain the speed or momentum of growth in banking and mobile money channels and service uptake. ROC is generally expressed as a ratio between a change in one variable relative to a corresponding change in another. Graphically, the rate of change is represented by the slope of a line. The calculation for ROC takes the current value and divides it by the value from an earlier period. By subtracting one 
and multiplying the resulting number by $100, \mathrm{ROC}$ is given as a percentage representation. $\mathrm{ROC}$ is demonstrated in the formula below.

$$
\text { ROC }=\left(\frac{\text { Current Value }}{\text { Previous Value }}-1\right) * 100
$$

The rate of change is used to mathematically describe the percentage change in value over a defined period. The rate of change (ROC) analysis reveals the speed at which a variable changes over a specific period. ROC is often applicable in the analysis of momentum.

\section{Findings} below.

The key findings of this study are organized under different sub-sections, as given

\subsection{Penetration of Bank Branches and Automated Teller Machines (ATMs)}

Branches of commercial banks increased from 140 in 2004 to 585 in 2019. The highest rate of growth (growth momentum) in the increases of bank branches took place between 2007 (21\%), 2008 (55\%), and 2009 (21\%). The rate of growth (growth momentum) in bank branches has plateaued at less than 7\% since 2014. Penetration of ATMs was fastest between 2008 and 2009. There was a reduction in the momentum of growth in ATMs in $2014(-5 \%)$ and since then, the rate of growth has plateaued at less than $8 \%$. This is presented in Table 1.

Table 1. Momentum of growth in bank branches and Automated Teller Machines (ATMs).

\begin{tabular}{|c|c|c|c|c|}
\hline Year & $\begin{array}{c}\text { Branches of } \\
\text { Commercial Banks }\end{array}$ & $\begin{array}{c}\text { ROC of Penetration of } \\
\text { Bank Branches (\%) }\end{array}$ & ATMs & $\begin{array}{c}\text { ROC of Penetration of } \\
\text { ATMs (\%) }\end{array}$ \\
\hline 2004 & 140 & 0 & 152 & 0 \\
\hline 2005 & 153 & 9 & 220 & 45 \\
\hline 2006 & 160 & 5 & 267 & 21 \\
\hline 2007 & 194 & 21 & 321 & 20 \\
\hline 2008 & 301 & 55 & 405 & 26 \\
\hline 2009 & 364 & 21 & 536 & 32 \\
\hline 2010 & 394 & 8 & 599 & 12 \\
\hline 2011 & 396 & 1 & 663 & 11 \\
\hline 2012 & 466 & 18 & 748 & 13 \\
\hline 2013 & 520 & 12 & 893 & 19 \\
\hline 2014 & 558 & 7 & 851 & -5 \\
\hline 2015 & 578 & 4 & 922 & 8 \\
\hline 2016 & 573 & -1 & 942 & 2 \\
\hline 2017 & 554 & -3 & 910 & -3 \\
\hline 2018 & 562 & 1 & 940 & 3 \\
\hline 2019 & 585 & 4 & 958 & 2 \\
\hline
\end{tabular}

Penetration of bank branches and ATMs per $1000 \mathrm{~km}^{2}$ and per 100,000 adults increased progressively since 2004. The number of commercial bank branches per $1000 \mathrm{~km}^{2}$ increased from less than 1 in 2004 to 3 in 2019 and the number of commercial bank branches per 100,000 adults increased from 1 in 2004 to about 3 in 2019. Penetration of bank branches and ATMs per $1000 \mathrm{~km}^{2}$ surpassed penetration of bank branches per 100,000 adults in 2015 . Penetration of bank branches and ATMs per $1000 \mathrm{~km}^{2}$ and per 100,000 adults is presented in Figure 1. 


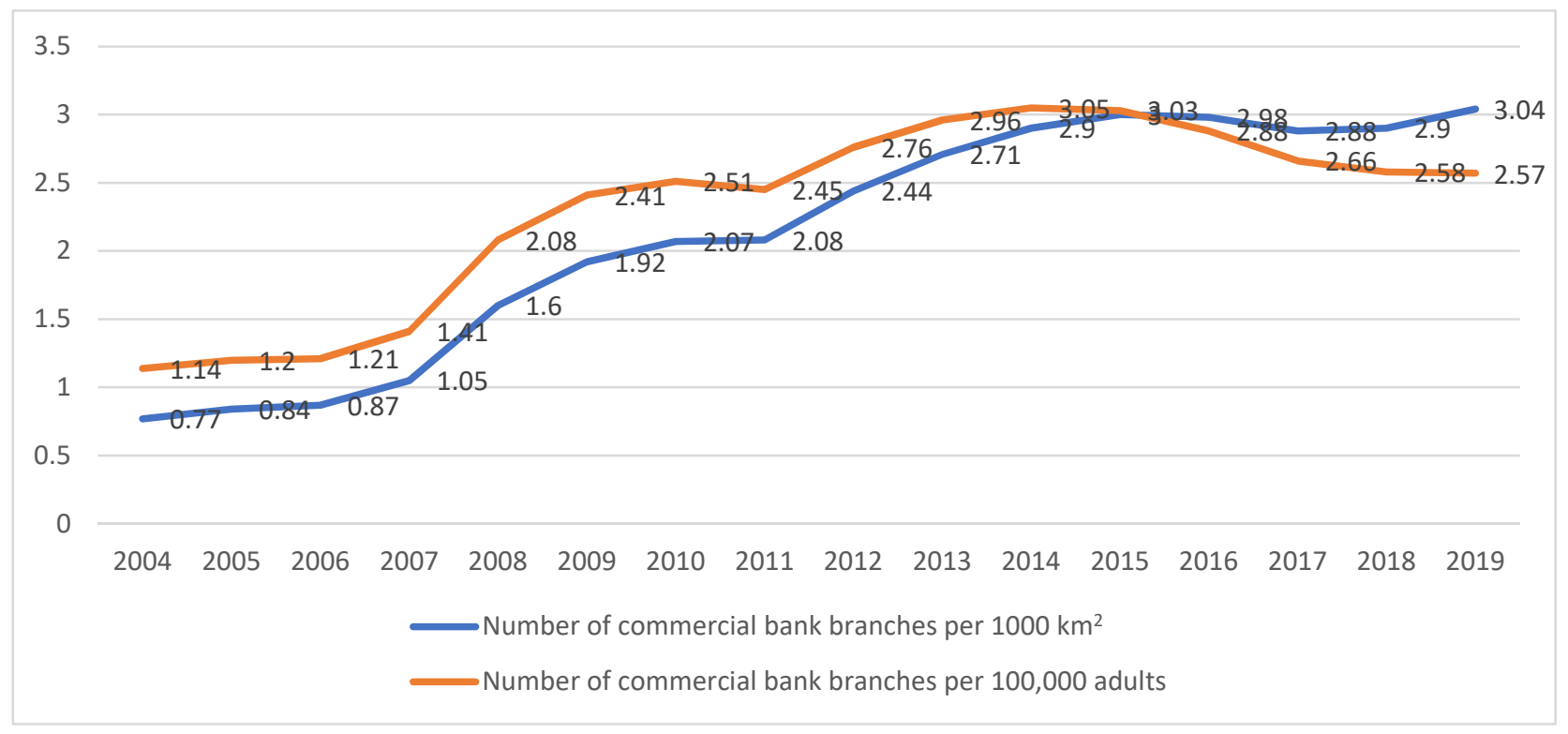

Figure 1. Penetration of bank branches and ATM per $1000 \mathrm{~km}^{2}$ and per 100,000 adults.

Overall, the penetration of ATMs per $1000 \mathrm{~km}^{2}$ and the penetration of ATMs per 100,000 adults increased since 2004. ATMs per $1000 \mathrm{~km}^{2}$ increased from less than 1 in 2004 to about 5 in 2019. Similarly, ATMs per 100,000 adults increased from 1 in 2004 to about 4 in 2019. The number of ATMs per $1000 \mathrm{~km}^{2}$ surpassed the number of ATMs per 100,000 adults in 2015. The penetration of bank branches and ATMs per $1000 \mathrm{~km}^{2}$ and per 100,000 adults is presented in Figure 2.

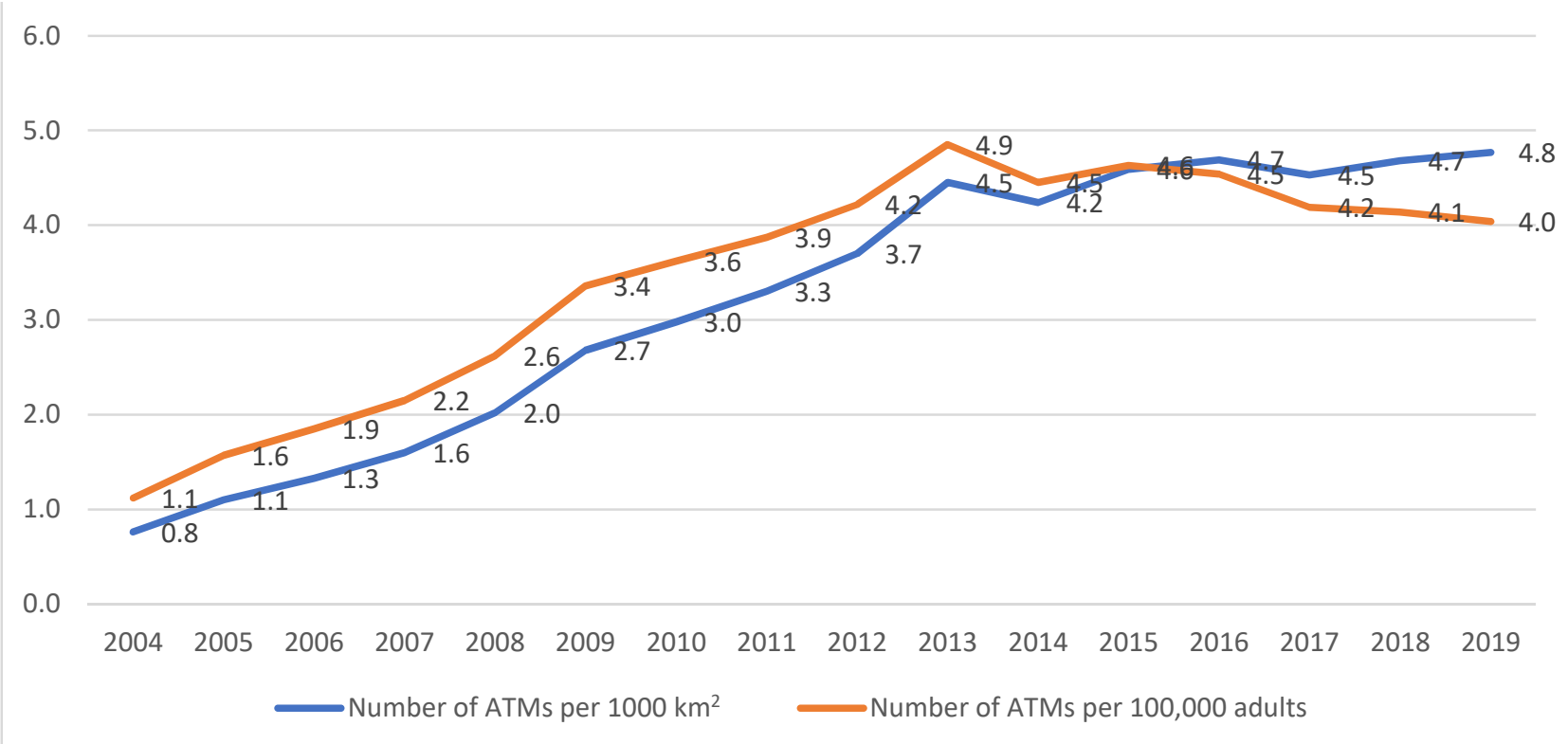

Figure 2. Number of ATMs per $1000 \mathrm{~km}^{2}$ and Number of ATMs per 100,000 adults.

\subsection{Uptake of Deposits}

Depositors increased from 1.2 million in 2004 to 6.8 million in 2019. Deposit accounts with commercial banks grew from 1.2 in 2004 to 12.8 million in 2019. The highest increases in depositors and deposits took place in 2008 (43\%) and 2017 (51\%). Mokash was introduced in August 2016. This may account for the increased number of depositors in 2017. When a 
mobile money subscriber opens up a Mokash account, they automatically also open up a virtual account at Commercial Bank of Africa (CBA) which is an MTN partner bank. Increased use of Mokash may have resulted in increased deposits. The growth momentum in depositors and deposit accounts reduced in 2011 and 2013. The trends in depositors and deposit accounts are presented in Table 2.

Table 2. Trends in depositors and deposit accounts with commercial banks.

\begin{tabular}{|c|c|c|c|c|}
\hline Year & $\begin{array}{l}\text { Depositors with } \\
\text { Commercial Banks } \\
\text { (Million) }\end{array}$ & $\begin{array}{l}\text { ROC of Depositors } \\
\text { with Commercial } \\
\text { Banks (\%) }\end{array}$ & $\begin{array}{c}\text { Deposit Accounts } \\
\text { with Commercial } \\
\text { Banks (Million) }\end{array}$ & $\begin{array}{c}\text { ROC of Deposits with } \\
\text { Commercial Banks } \\
(\%)\end{array}$ \\
\hline 2004 & 1.2 & 0 & 1.2 & 0 \\
\hline 2005 & 1.4 & 15 & 1.4 & 11 \\
\hline 2006 & 1.6 & 19 & 1.6 & 17 \\
\hline 2007 & 1.6 & 1 & 1.7 & 7 \\
\hline 2008 & 2.4 & 43 & 2.4 & 35 \\
\hline 2009 & 2.7 & 16 & 2.7 & 16 \\
\hline 2010 & 3.2 & 15 & 3.2 & 15 \\
\hline 2011 & 3.1 & -3 & 3.1 & -3 \\
\hline 2012 & 3.6 & 17 & 3.6 & 17 \\
\hline 2013 & 3.5 & -4 & 3.5 & -2 \\
\hline 2014 & 3.8 & 10 & 3.9 & 12 \\
\hline 2015 & 4.1 & 9 & 4.6 & 17 \\
\hline 2016 & 5.2 & 26 & 5.4 & 17 \\
\hline 2017 & 7.8 & 51 & 8.1 & 50 \\
\hline 2018 & 6.6 & -16 & 10.3 & 26 \\
\hline 2019 & 6.8 & 4 & 12.8 & 24 \\
\hline
\end{tabular}

Depositors per 1000 adults increased from 91 in 2004 to 290 in 2019. Deposit accounts with commercial banks per 1000 adults grew from 95 in 2004 to 539 in 2019. Deposit accounts with commercial banks per 1000 adults grew rapidly, surpassing depositors in 2015. The number of depositors with commercial banks per 1000 adults declined sharply between 2017 and 2018. The trends in depositors and deposit accounts with commercial banks per 1000 adults are presented in Table 3 .

Table 3. Trends in depositors and deposit accounts with commercial banks per 1000 adults.

\begin{tabular}{ccc}
\hline Year & $\begin{array}{c}\text { Number of Depositors with } \\
\text { Commercial Banks per 1000 Adults }\end{array}$ & $\begin{array}{c}\text { Number of Deposit Accounts with } \\
\text { Commercial Banks per 1000 Adults }\end{array}$ \\
\hline 2004 & 91 & 95 \\
2005 & 100 & 102 \\
2006 & 115 & 115 \\
2007 & 113 & 120 \\
2008 & 156 & 156 \\
2009 & 175 & 175 \\
2010 & 194 & 184 \\
2011 & 181 & 205 \\
2012 & 205 & 194 \\
2013 & 190 & 208 \\
2014 & 201 & 234 \\
2015 & 210 & 263 \\
2016 & 252 & 376 \\
2018 & 364 & 454 \\
\end{tabular}




\subsection{Uptake of Borrowing}

Data on borrowers from commercial banks for 2004 to 2009 were missing from the Financial Access Survey (FAS) dataset. Nonetheless, borrowers from commercial banks increased from less than half a million $(307,241)$ in 2010 to over 1.6 million in 2019. Loan accounts with commercial banks also increased from 309,000 in 2010 to 1.5 million in 2019. The highest rate of growth in borrowers from commercial banks and loan accounts with commercial banks was between 2017 and 2018 when borrowers from commercial banks increased by $134 \%$ and loan accounts with commercial banks increased by $141 \%$. Again, this could be on account of Mokash. In 2017, borrowers from commercial banks and loan accounts with commercial banks reduced. Noticeably, loan accounts with commercial banks surpassed borrowers from commercial banks in 2019. Borrowers from commercial banks and loan accounts with commercial banks are presented in Table 4.

Table 4. Momentum of growth in borrowers and loan accounts with commercial bank.

\begin{tabular}{ccccc}
\hline Year & $\begin{array}{c}\text { Borrowers from } \\
\text { Commercial Banks } \\
\mathbf{( 0 0 0 )}\end{array}$ & $\begin{array}{c}\text { ROC of Borrowers } \\
\text { from Commercial } \\
\text { Banks (\%) }\end{array}$ & $\begin{array}{c}\text { Loan Accounts with } \\
\text { Commercial Banks } \\
\text { (000) }\end{array}$ & $\begin{array}{c}\text { ROC of Loan Accounts with } \\
\text { Commercial Banks (\%) }\end{array}$ \\
\hline 2010 & 307 & 0 & 309 & 0 \\
2011 & 330 & 8 & 341 & 10 \\
2012 & 308 & -7 & 343 & 1 \\
2013 & 346 & 12 & 358 & 4 \\
2014 & 397 & 15 & 424 & 80 \\
2015 & 498 & 25 & 765 & -4 \\
2016 & 677 & 36 & 736 & -7 \\
2017 & 671 & -1 & 688 & 19 \\
2018 & 1572 & 134 & 1659 & -8 \\
2019 & 1675 & 7 & 1532 & \\
\hline
\end{tabular}

The number of borrowers from commercial banks per 1000 adults and the number of loan accounts with commercial banks per 1000 adults grew during the period covered in this study. The number of borrowers from commercial banks per 1000 adults increased from 19 in 2010 to 71 in 2019. Similarly, the number of loan accounts with commercial banks per 1000 adults grew from 19 in 2010 to 65 in 2019. Borrowers from commercial banks per 1000 adults and loan accounts with commercial banks per 1000 adults are presented in Table 5.

Table 5. Borrowers and loan accounts with commercial banks from commercial banks per 1000 adults.

\begin{tabular}{cccc}
\hline Year & $\begin{array}{c}\text { Number of Borrowers from } \\
\text { Commercial Banks per 1000 Adults }\end{array}$ & $\begin{array}{c}\text { Number of Loan Accounts with } \\
\text { Commercial Banks per 1000 Adults }\end{array}$ \\
\hline 2010 & 19 & 19 \\
2011 & 19 & 20 & 19 \\
2012 & 17 & 19 & 22 \\
2013 & 19 & 38 \\
2014 & 21 & 35 \\
2015 & 25 & 32 \\
2017 & 31 & 73 \\
2018 & 69 & 65 \\
\hline
\end{tabular}




\subsection{Mobile Money}

Data on registered mobile money agent outlets for 2004 to 2012 were missing from the Financial Access Survey (FAS) dataset. Mobile money agent outlets increased from 53,000 in 2012 to 212,000 in 2019. The highest ROC (momentum) of registered mobile money agent outlets was in $2014(48 \%)$. Penetration of mobile money agent outlets continues to increase although ROC (momentum) of registered mobile money agent outlets remained unchanged at 15\% in 2018 and 2019. The rate of change of mobile money agent outlets is presented in Table 6.

Table 6. Penetration of mobile money agent outlets.

\begin{tabular}{ccc}
\hline Year & $\begin{array}{c}\text { Registered Mobile Money Agent } \\
\text { Outlets (000) }\end{array}$ & $\begin{array}{c}\text { ROC of Penetration of Registered } \\
\text { Mobile Money Agent Outlets (\%) }\end{array}$ \\
\hline 2013 & 53 & 0 \\
2014 & 79 & 48 \\
2015 & 109 & 39 \\
2016 & 132 & 21 \\
2017 & 159 & 20 \\
2018 & 184 & 15 \\
2019 & 212 & 15 \\
\hline
\end{tabular}

The number of registered mobile money agent outlets per 100,000 adults and the number of registered mobile money agent outlets per $1000 \mathrm{~km}^{2}$ increased linearly from 2013 to 2019. Registered mobile money agent outlets per 100,000 adults increased from 291 in 2013 to 897 in 2019. Similarly, registered mobile money agent outlets per $1000 \mathrm{~km}^{2}$ increased from 267 in 2013 to 1060 in 2019. The penetration of mobile money agent outlets per 100,000 adults and per $1000 \mathrm{~km}^{2}$ is presented in Figure 3.

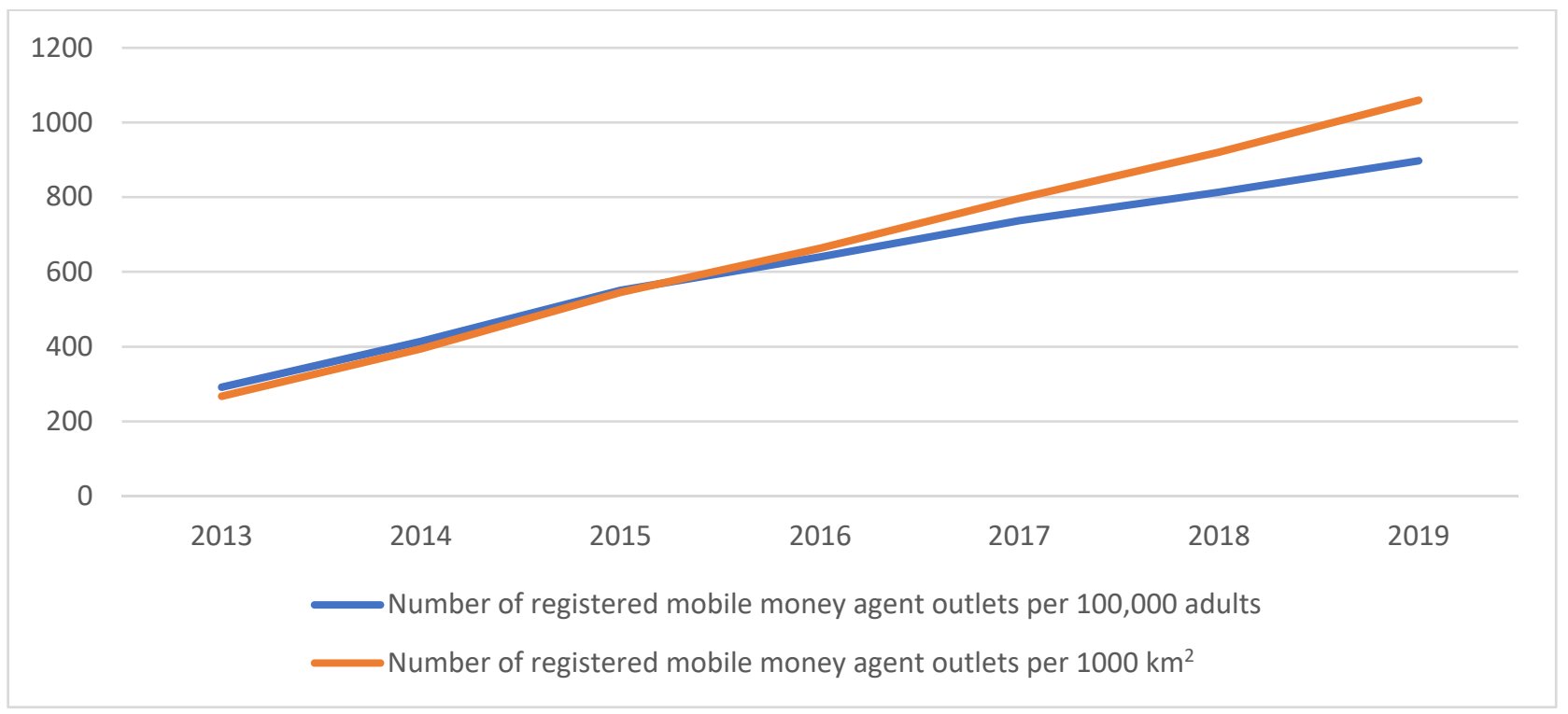

Figure 3. Mobile money agent outlets per 100,000 adults and per $1000 \mathrm{~km}^{2}$.

\subsection{Uptake of Mobile Money Services}

Registered mobile money accounts grew so fast, from just about 552,000 in 2009 to 27 million in 2019. The rate of change (momentum) in registered mobile money accounts spiraled in $2010(205 \%)$ and $2012(208 \%)$. Since 2014, the number of registered mobile money accounts has continued to grow but at a reduced rate. The number of mobile money transactions grew from 2.8 million in 2009 to 2.8 million in 2019. The number of mobile 
money transactions also underwent the highest increases in 2010 (915\%) and 2011 (204\%).

Table 7 shows growth in mobile money transactions.

Table 7. Growth in mobile money accounts and mobile money transactions.

\begin{tabular}{|c|c|c|c|c|}
\hline Year & $\begin{array}{c}\text { Number of Registered } \\
\text { Mobile Money } \\
\text { Accounts }(000,000)\end{array}$ & $\begin{array}{l}\text { ROC of Registered } \\
\text { Mobile Money } \\
\text { Accounts (\%) }\end{array}$ & $\begin{array}{l}\text { Number of Mobile } \\
\text { Money Transactions } \\
(000,000)\end{array}$ & $\begin{array}{c}\text { ROC of Mobile } \\
\text { Money Transactions } \\
(\%)\end{array}$ \\
\hline 2009 & 0.5 & 0 & 2.8 & 0 \\
\hline 2010 & 1.6 & 205 & 28.8 & 915 \\
\hline 2011 & 2.8 & 71 & 87.5 & 204 \\
\hline 2012 & 8.8 & 208 & 242 & 177 \\
\hline 2013 & 14.2 & 60 & 399 & 65 \\
\hline 2014 & 18.8 & 32 & 496 & 24 \\
\hline 2015 & 21.1 & 12 & 694 & 40 \\
\hline 2016 & 21.6 & 2 & 975 & 40 \\
\hline 2017 & 22.8 & 6 & 1090 & 12 \\
\hline 2018 & 24.5 & 7 & 1880 & 72 \\
\hline 2019 & 27.1 & 11 & 2840 & 51 \\
\hline
\end{tabular}

Data on the number of active mobile money accounts per 1000 adults were only available for 2018 and 2019. Nonetheless, the number of registered mobile money accounts per 1000 adults grew from 35 in 2009 to more than 1000 in 2019. Active mobile money accounts per 1000 were over 600 in 2018 and 2019. Around 2016, UCC disconnected accounts that were not registered. This might account for the drop in ROC to just $2 \%$ in 2016. Registered mobile money accounts per 1000 adults and active mobile money accounts per 1000 adults are presented in Figure 4.

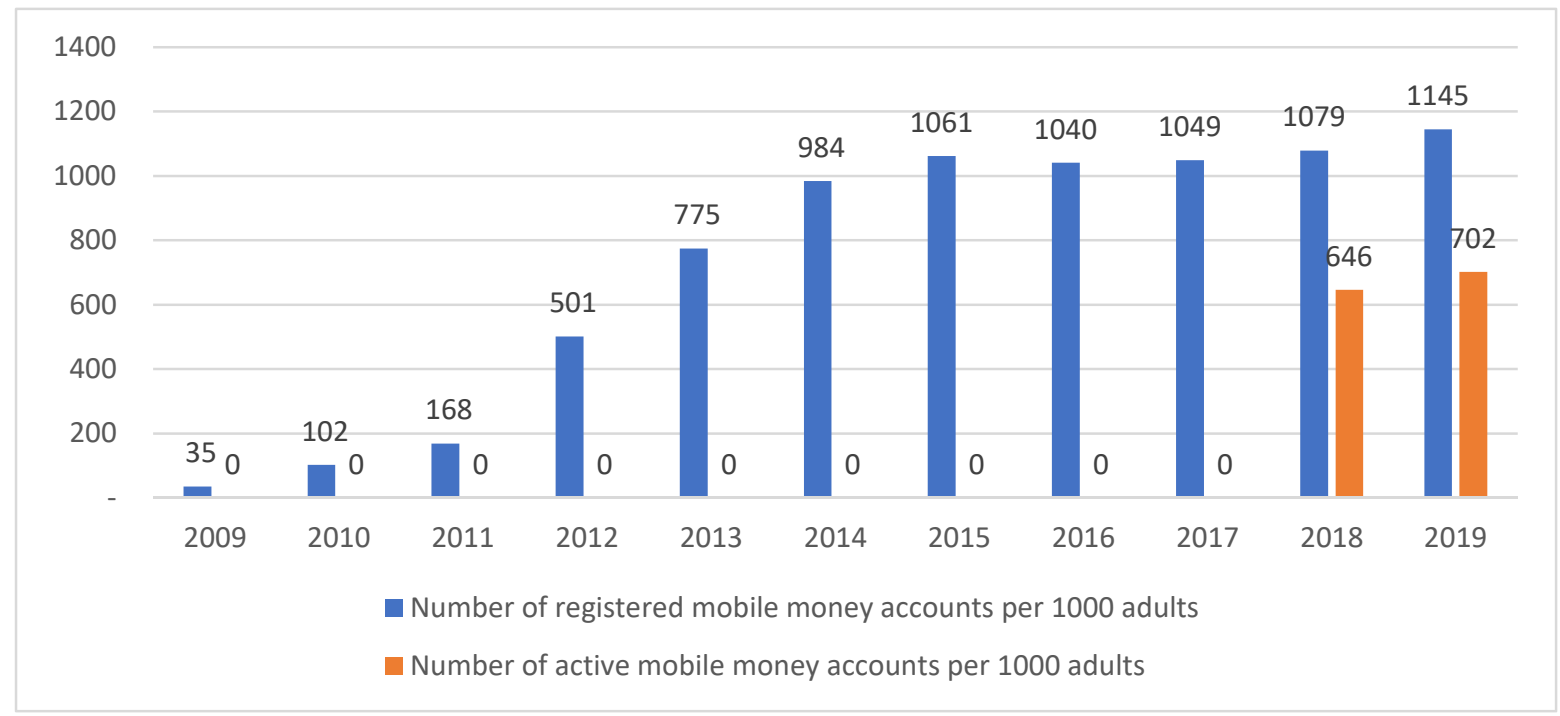

Figure 4. Registered mobile money accounts and active mobile money accounts per 1000 adults.

Mobile money transactions per 1000 adults increased from about 180 in 2009 to about 120,000 in 2019. The fastest growth in the number of mobile money transactions per 1000 adults was encountered between 2017 when there were 50,000 transactions per 1000 adults and 2019 when there were about 120,000 transactions per 1000 adults. Figure 5 shows growth in mobile money transactions per 1000 adults. 


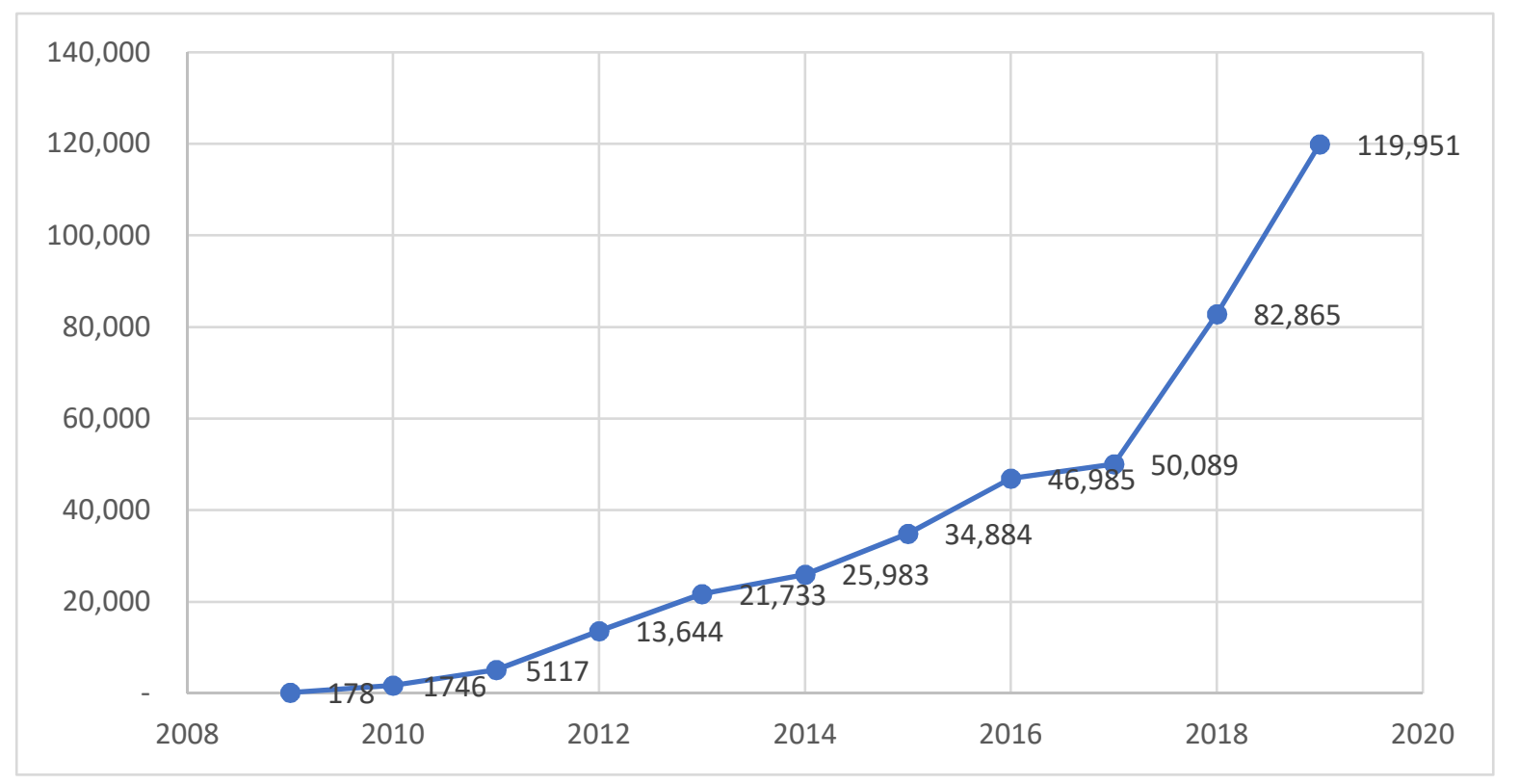

Figure 5. Growth in mobile money transactions per 1000 adults.

\section{Discussion}

Branches of commercial banks increased from 140 in 2004 to 585 in 2019. Growth in bank branches slowed down since 2014 and has since then plateaued around 550 and 580. Similarly, the increase in ATMs was faster between 2004 and 2013 and has slowed down since 2013. The plateauing of branches and ATMs is attributable to service users switching to digital, and particularly, mobile access of their accounts. The preference for mobile access is driven by customer's preference for convenience. Plateauing growth in banking threatens to slow down the contribution of banking in enhancing financial inclusion. Depositors increased from 1.2 million in 2004 to 6.8 million in 2019. Deposit accounts with commercial banks grew from 1.2 in 2004 to 12.8 million in 2019. The highest increases in depositors and deposits took place in 2008 and 2017.

Given the role of banking in enhancing financial inclusion, channel innovations are needed for banking to regain its role in enhancing financial inclusion. Annual reports of most banks show significant growth of digital channels. Leveraging the application of digital innovations in services such as payments and digitizing alternative channels such as agent banking are likely to increase efficiencies in the provision of banking services and thereby increase reach and penetration of banking. Notably, the traditional bank branches remain relevant in such cases. Product innovation is likely to drive uptake and usage of deposits and borrowings. Appropriate partnerships are likely to enable banks and partners to innovate and come up with relevant products.

Mobile money agent outlets increased from 53,000 in 2012 to 212,000 in 2019. The highest ROC (momentum) of registered mobile money agent outlets was in 2014 (48\%). Penetration of mobile money agent outlets continues to increase although ROC (momentum) of registered mobile money agent outlets remained unchanged at 15\% in 2018 and 2019. This is consistent with the trend observable in other jurisdictions such as Asia and West Africa (Aron 2018; IMF 2019b). The fast pace of mobile money penetration has two opposing implications. On a positive note, this is good for enhancing financial inclusion (GSMA 2016). On the other hand, the fast growth in mobile money calls for better approaches for consumer protection. Unlike in the case of banks, approaches for consumer protection in the case of mobile money are still evolving. Literature on principles of consumer protection in Digital Financial Services (AFI 2014) is useful to strengthen consumer protection in the case of mobile money. 
The fast pace of mobile money penetration also bears implications for addressing integrity (Chatain et al. 2013; de Koker 2013), criminal (de Koker 2013), privacy and data laws (CFI 2021; Harris et al. 2013; UCC 2021), indebtedness (Ebong and George 2020) risks of DFS. Approaches and strategies that can help manage DFS and associated risks may include; licensing and policing Fintechs and the payment space; encouraging self-regulation, including ensuring the Financial Services Providers (FSP), Payment Services Providers (PSP s), and Fintechs have internal policies and procedures that support managing of DFS risks; engaging industry association such as Uganda Bankers Association (UBA), Financial Technology Service Providers Association (FITSPA) to raise awareness and support members in deliberating and coming up with solutions for addressing DFS risks.

Registered mobile money accounts grew so fast, from just about 552,000 in 2009 to 27 million in 2019. The rate of change (momentum) in registered mobile money accounts spiraled in 2010 (205\%) and 2012 (208\%). The number of mobile money transactions grew from 28 million in 2009 to 2.8 billion in 2019. Mobile money transactions per 1000 adults increased from about 180 in 2009 to about 120,000 in 2019. The fastest growth in the number of mobile money transactions per 1000 adults was encountered between 2017 when there were 50,000 transactions per 1000 adults and 2019 when there were about 120,000 transactions per 1000 adults.

Given a global convergence in mobile money and banking (IMF 2019b), partnership that brings together banks and MNOs carry advantages for both categories of partners and allows for both partners to benefit from the strengths of each. Banks tend to be trusted more, especially because they are regulated better. Mobile money and MNOs provide rails or digital infrastructure for innovations. Fintechs tend to innovate along with the infrastructure provided by MNOs to come up with new products. MNOs and Fintechs bring into partnerships agility in innovation.

\section{Conclusions}

The rate of change or momentum of penetration in bank branches and ATMs has plateaued at less than $10 \%$ since 2014 . Plateauing growth in banking threatens to slow down the contribution of banking in enhancing financial inclusion. Several studies on banking (Agarwal and Mehrotra 2017; Mishra and Singh 2015; etc.) show that human interaction (Ayyagari and Parahoo 2018), through physical channels and interactions with customer service representatives (CSRs) enhances the satisfaction of customers who are digitally antagonistic and boosts usage of services. Channel (Agarwal and Mehrotra 2017) and product innovations are needed if banking is to regain its role in enhancing financial inclusion. Penetration of mobile money agent outlets continues to increase although the growth in the momentum of registered mobile money agent outlets remained unchanged at $15 \%$ in 2018 and 2019. The growth momentum is good for enhancing financial inclusion (GSMA 2016). However, this calls for better approaches for consumer protection (AFI 2014).

There is a convergence between banking and mobile money channels (Myeni et al. 2020). Partnerships that bring together banks and MNOs carry advantages for both categories of partners and allows for both partners to benefit from the strengths of each. Banks tend to be trusted more, especially because they are regulated better, and MNOs and Fintech are likely to bring agility in innovation into the partnership.

Several studies on banking show that despite the proliferation of channel digitization initiatives, human interaction through physical channels and interactions with customer service representatives (CSRs) enhances the satisfaction of digitally-averse customers hence boosting usage of services. Unfortunately, IMF's FAS data show that the rate of change or momentum of penetration in bank branches and ATMs has plateaued at less than $10 \%$ since 2014. The opportunity for the banking sector is to leverage digitization on the human touch particularly with CSRs at physical branches. Therefore, further studies should investigate the following. 
(a) The extent to which leveraging digitization to CSRs is likely to grow or increase uptake and usage of banking services, especially among customers who experience digital aversion and prefer to encounter and experience interactions with CSR.

(b) The extent to which banks can attain efficiency by leveraging alternative channels to the existing physical channels (bank branch) to increase efficiency and competitiveness.

Clearly, both banking and mobile money channels have inherent advantages. It is recommended that banks must collaborate with MNOs to innovate to enhance financial inclusion. Channel innovations, which may infuse banking and mobile money are needed for banking to leverage on the growth of mobile money and regain its role in enhancing financial inclusion. Leveraging the application of digital innovations in services such as payments and digitizing alternative channels such as agent banking are likely to increase efficiencies in physical channels and the provision of banking services and thereby increase overall reach and penetration of banking. The fast pace of mobile money penetration is good for speeding financial inclusion. However, this calls for better regulatory approaches for DFS risk reduction and increased consumer protection.

Author Contributions: Conceptualization, J.E.; Methodology, J.E.; software, J.E.; validation, J.E. and B.G.; formal analysis, J.E.; investigation, J.E.; resources, J.E. and B.G.; data curation, J.E.; writingoriginal draft preparation, J.E. and B.G.; writing—review and editing, J.E. and B.G.; visualization, J.E. and B.G.; supervision, B.G.; project administration, J.E. Both authors have read and agreed to the published version of the manuscript.

Funding: This research received no external funding.

Data Availability Statement: Data supporting reported results can be found on the FAS website on the link: https: / / data.imf.org/?sk=E5DCAB7E-A5CA-4892-A6EA-598B5463A34C (accessed on 9 April 2021).

Conflicts of Interest: The authors declare no conflict of interest.

\section{References}

AFI. 2014. Mobile Financial Services Consumer Protection in Mobile Financial Services. Available online: https://www.afi-global.org/ sites/default/files/publications/mfswg_guideline_note_7_consumer_protection_in_mfs.pdf (accessed on 12 April 2021).

Agarwal, Reeti, and Ankit Mehrotra. 2017. An Analysis of Adoption Pattern of Alternative Banking Channels by Indian Customers. IUP Journal of Marketing Management 16: 65-80.

Ahmad, Ahmad Hassan, Christopher Green, and Fei Jiang. 2020. Mobile Money, Financial Inclusion and Development: A Review with Reference to African Experience. Journal of Economic Surveys 34: 753-92. [CrossRef]

Amoah, Anthony, Kofi Korle, and Rexford Kweku Asiama. 2020. Mobile money as a financial inclusion instrument: What are the determinants? International Journal of Social Economics 47: 1283-97. [CrossRef]

Angela, Angulo. 2016. Pros and Cons of Using Existing Statistics and Secondary Data. Available online: https://rampages.us/ angelaangulo/2016/11/09/pros-and-cons-of-using-existing-statistics-and-secondary-data/ (accessed on 31 May 2021).

Aron, Janine. 2018. Mobile Money and the Economy: A Review of the Evidence. World Bank Research Observer 33: 135-88. [CrossRef]

Ayyagari, Madhavi, and Sanjai K. Parahoo. 2018. Personal touch or convenient tech? An investigation of customer channel preferences in retail banking. International Journal of Financial Services Management 9: 103-18. [CrossRef]

Banto, Jean Michel, and Atokê Fredia Monsia. 2021. Microfinance institutions, banking, growth and transmission channel: A GMM panel data analysis from developing countries. Quarterly Review of Economics \& Finance 79: 126-50. [CrossRef]

CFI. 2021. The Stories Algorithms Tell: Bias and Financial Inclusion at the Data Margins. Available online: https://content. centerforfinancialinclusion.org/wp-content/uploads/sites/2/2021/03/The-Stories-Algorithms-Tell-CFI-publication-MAR21. pdf (accessed on 14 August 2021).

Chatain, Pierre-Laurent, Andrew Zerzan, Wameek Noor, Najah Dannaoui, and Louis de Koker. 2013. Protecting Mobile Money against Financial Crimes. Global Policy Challenges and Solutions. Available online: https://elibrary.worldbank.org/doi/abs/10.1596/ 978-0-8213-8669-9 (accessed on 14 August 2021).

de Koker, Louis. 2013. The 2012 Revised FATF Recommendations: Assessing and Mitigating Mobile Money Integrity Risks Within the New Standards Framework. 8 Wash. J. L. Tech. and Arts 165. Available online: https://digitalcommons.law.uw.edu/cgi/viewcontent. cgi? article $=1164 \&$ context $=$ wjlta (accessed on 14 August 2021).

de koker, louis. 2018. ML/FT risk and financial inclusion of the poor: Increase the focus on actual usage of formal financial services. Journal of Money Laundering Control 21: 250-52. [CrossRef] 
Ebong, Jimmy, and Badu George. 2020. Demand for credit in high-density markets in Kampala: Application of digital lending and implications for product innovation. Journal of International Studies 13: 295-313. [CrossRef]

El-Zoghbi, Mayada. 2019. Does Financial Inclusion Impact the Lives of the Poor? Available online: https://www.cgap.org/blog/doesfinancial-inclusion-impact-lives-poor (accessed on 12 April 2021).

FSDU. 2018. Finacope Uganda 2018 Survey Report. Available online: https:/ / fsduganda.or.ug/finscope-2018-survey-report/ (accessed on 12 April 2021).

GPFI. 2016. Global Standard-Setting Bodies and Financial Inclusion: The Evolving Landscape. White Paper. Washington, DC: CGAP, Available online: https:/ / www.gpfi.org/sites/gpfi/files/documents/GPFI_WhitePaper_Mar2016.pdf (accessed on 14 August 2021).

GSMA. 2016. Safeguarding Mobile Money: How Providers and Regulators Can Ensure that Customer Funds Are Protected. Available online: https://www.gsma.com/mobilefordevelopment/wp-content/uploads/2016/01/2016_GSMA_Safeguarding-MobileMoney_How-providers-and-regulators-can-ensure-that-customer-funds-are-protected.pdf (accessed on 12 April 2021).

GSMA. 2017. State of the Industry Report on Mobile Money. Available online: https://www.gsma.com/mobilefordevelopment/wpcontent/uploads/2018/05/GSMA_2017_State_of_the_Industry_Report_on_Mobile_Money_Full_Report.pdf (accessed on 12 April 2021).

Harris, Andrew, Seymour Goodman, and Patrick Traynor. 2013. Privacy and Security Concerns Associated with Mobile Money Applications in Africa. 8 Wash. J. L. Tech. \& Arts 245. Available online: https://digitalcommons.law.uw.edu/cgi/viewcontent.cgi?article=1173 \&context=wjlta (accessed on 14 August 2021).

Hermes, Niels. 1994. Financial development and economic growth: A survey of the literature. International Journal of Development Banking 12: 3-22.

IMF. 2019a. Financial Access Survey Guidelines and Manual. Available online: file:/ / C:/Users/HP/Downloads/Financial\%20 Access\%20Survey\%20Guidelines\%20and\%20Manual\%20(English).pdf (accessed on 14 August 2021).

IMF. 2019b. Financial Access Survey Trends and Development. Available online: file:/ / C:/Users/HP/Downloads/2019\%20FAS\%20 Trends\%20and\%20Developments.pdf (accessed on 14 August 2021).

IMF. 2021. Measuring Digital Financial Inclusion in Emerging Market and Developing Economies: A New Index WP21/90. Available online: file:/ / /C:/Users /HP / Downloads/wpiea2021090-print-pdf.pdf (accessed on 14 August 2021).

Iqbal and Sami. 2017. Role of Banks in Financial Inclusion in India. Available online: http://www.scielo.org.mx/pdf/cya/v62n2/018 6-1042-cya-62-02-00644.pdf (accessed on 28 May 2021).

Kar, Muhsin, Şaban Nazlığlu, and Hüseyin Ağır. 2011. Financial development and economic growth nexus in the MENA countries: Bootstrap panel granger causality analysis. Economic Modelling 28: 685-93. [CrossRef]

Kaur, Simran Jit, Liaqat Ali, M. Kabir Hassan, and Md Al-Emran. 2021. Adoption of digital banking channels in an emerging economy: Exploring the role of in-branch efforts. Journal of Financial Services Marketing 26: 107-21. [CrossRef]

Khan, Mohsin S., and Abdelhak S. Senhadji. 2003. Financial development and economic growth: A review and new evidence. Journal of African Economies 12: ii89-ii110. [CrossRef]

Kumar, Nitin. 2013. Financial inclusion and its determinants: Evidence from India. Journal of Financial Economic Policy 5: 4-19. [CrossRef]

Lashitew, Addisu, Rob van Tulder, and Yann Liasse. 2019. Mobile phones for financial inclusion: What explains the diffusion of mobile money innovations? Research Policy 48: 1201-15. [CrossRef]

Levine, Ross. 1997. Financial development and economic growth: Views and agenda. Journal of Economic Literature 35: 688-726.

Merritt, Cynthia. 2011. Mobile money transfer services: The next phase in the evolution of person-to-person payments. Journal of Payments Strategy E Systems 5: 143-60.

Mishra, Vaibhav, and Vrijendra Singh. 2015. Selection of appropriate electronic banking channel alternative. International Journal of Bank Marketing 33: 223-42. [CrossRef]

Myeni, Siphesihle, Marshall Makate, and Nyasha Mahonye. 2020. Does mobile money promote financial inclusion in Eswatini? International Journal of Social Economics 47: 693-709. [CrossRef]

Nkuna, Onelie, Agella Lapukeni, Paxon Kaude, and Grant Kabango. 2018. The Role of Commercial Banks on Financial Inclusion in Malawi. Open Journal of Business and Management 6: 812-32. [CrossRef]

Noronha, Michael, and V. Rajesh Kumar. 2019. Technology: A Tool for Achieving Inclusive and Sustainable Growth through Financial Inclu-668 sion. Clear International Journal of Research in Commerce \& Management 10: 1-5.

Nyimbiri, Bydon Austin. 2021. The Impact of the Mobile Money on People's Use of Financial Services in Sub-Sahara Africa. Management Dynamics in the Knowledge Economy 9: 137-46. [CrossRef]

Ogden, Tim. 2019. Learning from Financial Inclusion Research: What Should We Expect? Available online: https://www.cgap.org/ blog/learning-financial-inclusion-research-what-should-we-expect (accessed on 12 April 2021).

Ouma, Shem Alfred, Teresa Maureen Odongo, and Maureen Were. 2017. Mobile financial services and financial inclusion: Is it a boon for savings mobilization? Review of Development Finance 7: 29-35. [CrossRef]

Robinson, Joan. 1952. The Generalization of the General Theory, the Rate of Interest and Other Essays. London: Macmillan, pp. 67-142.

Schumpeter, Joseph. 1911. The Theory of Economic Development. Harvard Economic Studies. Cambridge: Harvard University Press, vol. XLVI.

Trew, Alex. 2006. Finance and growth: A critical survey. Economic Record 82: 481-90. [CrossRef] 
UCC. 2020. Market Performance Report. Available online: https://www.ucc.co.ug/wp-content/uploads/2021/01/MarketPerfomance-Report-Q3-2020-Final-compressed.pdf (accessed on 14 August 2021).

UCC. 2021. Market Performance Report. Available online: https://www.ucc.co.ug/wp-content/uploads/2021/07/UCC_1q21-MarketPerfomance-Report_-compressed.pdf (accessed on 14 August 2021).

Vidyashree, D. V., and Pralhad Rathod. 2018. Problems encountered by Indian Commercial Banks customers while using IT-enabled banking services through E-channels in Bangalore City-An Empirical Study. BVIMSR Journal of Management Research 10: 77-84.

Xv, Lingbo, and Qingjun Meng. 2015. Interference in and Ecological Strategies to Mobile Financial Services Developed by Commercial Banks. Open Journal of Social Sciences 3: 194. Available online: https://www.scirp.org/pdf/JSS_2015071615484165.pdf (accessed on 28 May 2021). [CrossRef] 